\title{
How to Cite:
}

Kovalenko, O. V., Yepyk, L. I., Yeromenko, A. Y., Kashynska, O. Y., \& Bezruchenkov, Y. V. (2021). Training of the future tourist guides for intercultural communicative interaction within professional activity. Linguistics and Culture Review, 5(S4), 729-746.

https://doi.org/ 10.21744/lingcure.v5nS4.1712

\section{Training of the Future Tourist Guides for Intercultural Communicative Interaction within Professional Activity}

\author{
Oleksandr V. Kovalenko
}

Sumy State Pedagogical University named after A.S. Makarenko, Sumy, Ukraine

\section{Larysa I. Yepyk}

Sumy State Pedagogical University named after A.S. Makarenko, Sumy, Ukraine

\author{
Andrii Yu. Yeromenko \\ Sumy State Pedagogical University named after A.S. Makarenko, Sumy, Ukraine
}

Olena Ye. Kashynska

Luhansk Taras Shevchenko National University, Starobilsk, Ukraine

\section{Yurii V. Bezruchenkov}

Luhansk Taras Shevchenko National University, Starobilsk, Ukraine

\begin{abstract}
This study argues for the significance of the cultural approach to the professional training of the future tourist guide for intercultural communicative interaction. Notably, meeting the constantly growing needs of the tourist market consumer is a pressing issue. It is emphasised that the professional training of a specialist in this field should be focused on providing a high quality theoretical and practical training for a specialist to be ready for professional and communicative interaction with consumers of tourist services. Intercultural communication is seen as a purposeful connection between different cultures, which performs an exchange of information, cultural and spiritual value through professional activities to meet the needs of tourists, while taking into account the uniqueness of every culture. When interacting with the audience, the guide uses methods of pedagogical influence, which are based on didactic principles (scientific, ideological, connection with real life, accessibility, system, responsiveness and persuasiveness). They define the content, organisation and methods of educating tourists during the excursion, regardless of them being children or adults. The excursion method is the basis of the tour and is a compilation of the ways for the guide to share the knowledge and tourists' reception of
\end{abstract}

Linguistics and Culture Review (c) 2021.

Corresponding author: Kovalenko, O.V.; Email: kovalenko6512@lund-univer.eu

Manuscript submitted: 18 July 2021, Manuscript revised: 27 Oct 2021, Accepted for publication: 3 Nov 2021 
this knowledge. Personal qualities associated with understanding people's inner world and humane treatment are crucial for the future guide. Travel services reveal the inner world of a person in new aspects, accompanied by the emergence of new emotions and psychological relief. In this process, intellectual, sensory, cognitive efforts are made in a non-linear way for enriching the social experience, regardless of a person's financial status (which to some extent is the democracy of tourism). The main aspects of professional training of the future guide for the intercultural communicative interaction in professional activities are presented.

Keywords---cultural studies approach in education, intercultural communicative interaction, pedagogy of tourism, standard for preparation of guides, the guide.

\section{Introduction}

Nowadays, a tour guide is considered as a special profession, which must correspond to a certain personality type, which possesses specific interests and abilities, and a certain combination of individual, psychophysiological and physical features. Personal qualities associated with understanding people's inner world and humane treatment are crucial for the future guide. The modern civilisational development is discussed within the framework of its components, which are the economy, social sphere and spiritual culture. The global factor that affects each of the above components is world tourism as a social phenomenon with a variety of meanings and manifestations. Tourism affects the stability of society by fostering tolerance and hospitality and forms a communicative culture and public diplomacy that enhance consolidation of the nation. At the beginning of the $21^{\text {st }}$ century, tourism began to develop globally, which was caused by the voluntary temporary migration of large numbers of people to another environment with a specific tourist purpose (Miloradov et al., 2018). Due to this mass traveling to another socio-cultural environment, intercultural communications intensify, which signifies tourists' knowledge in various fields, and economic and cultural connections between ethnic groups and peoples become tighter. The problem of consumers' satisfaction with the tourist market services becomes especially relevant (Gültekin \& Icigen, 2019; Báez et al., 2020).

Travel services reveal the new aspects of a person's inner world, accompanied by the emergence of new emotions and psychological relief. In this process, intellectual, sensory, cognitive efforts are made in a non-linear way for enriching the social experience, regardless of a person's financial status (which to some extent is the democracy of tourism). Therefore, special attention should be paid to the training of staff in this field. The training programmes for guides that are used today, as well as their content and regulatory framework do not fully reflect the demands of the tourism practice. This aggravates the problem of developing a professionally oriented pedagogical practice that provides the modern professional knowledge, skills and abilities for organisation and management of excursions. It is necessary to design systems of professional development of teachers and employees of the tourism industry considering the specifics of the content of 
professional training of a tourist guide, as well as the mandatory adoption of a single professional standard for training guides, adoption of the experience of European countries, unification of the requirements and standards for the training of tourist guides (Amandykova et al., 2016). As for now, the meaningful basis for professional training of tourist guides is culture, which encompasses values, meaningful knowledge, and ideas, which are reflected in art, religion, tradition and human experience (Litovka-Demenina, 2019). However, the conventional system of education proposes a narrow understanding of the cultural studies approach, which is its reduction to the cultural studies aspect, the principle of cultural centrism, which indicates the lack of its methodological argumentation and incomplete use of opportunities in this field (Shmeleva \& Spasskii, 2018).

A crucial condition for the implementation of a cultural studies approach to the training of guides is their spiritual and moral development (Liu, 2018; Suyasa et al., 2016). The spiritual potential of a specialist is determined by the degree of one's involvement not only in the global culture but also in national and cultural traditions (Bretsko \& Morgun, 2019). Not so long ago, ethnic traditions were considered to be almost a forbidden topic in Ukraine. Personality was interpreted within the framework of society, outside the ethnic group. Nowadays, when different national cultural traditions start a dialogue, they interact and enrich each other (Absatova et al., 2021; Fatmawati, 2021). There are favourable opportunities for the guide to understand the processes of internationalisation of public life, the development and functioning of human culture in general (Ang, 2005). One of the key aspects in the implementation of the cultural studies approach is the need to ensure the cultural identification of the future guide. Notably, the cultural studies approach in relation to the professional activity of a guide has a number of nuances in which the dialectic of this concept is revealed. First of all, this professional activity itself is an integral part, a cultural phenomenon (Suwija et al., 2019). Therefore, its development can be ensured only within the social, cultural, and historical framework. However, the professional activity of the guide is not only about cultural self-development but also about the process of transmission and translation of cultural patterns of life and behaviour (Di Nezza et al., 2012). It is vital that this process develops in the context of culture, so that its results will be not only utilitarian knowledge, skills and abilities but also the mastered values of culture (Caber et al., 2019; Ghahramani et al., 2018).

\section{Literature Review}

Analysis of recent research and published sources has shown that scholars have thoroughly investigated the primary problems of training guides (Sakun, 2004; Báez et al., 2020), improving their skills (Gültekin \& Icigen, 2019; Dashevska \& Tomkovich, 2018; Hwang \& Lee, 2019), sustainable development of the school of excursion in Ukraine (Nychkalo, 2000; Yaksa, 2006; Yevdokimova-Lysohor, 2018; Holovashenko, 2002). Some scholars have investigated the issues of guides' course training (Nychkalo, 2000; Ghahramani et al., 2018; Maddamsetti, 2020), development and improvement of excursion methods and organisation of excursion activities (Caber et al., 2019; Edelheim, 2020; Lee \& Moon, 2020). In addition, scholars were interested in pedagogical research on problems of 
development of the content of professional education in the field of excursion activities (Fedorchenko, 2002; Fedorchenko et al., 2004). The main prerequisites for the development of the domestic tourism industry are the establishment of the effective system of training tourism professionals. This implies not only the development of a tourist educational and pedagogical system but also the improvement of the organisation of the education of specialists in the tourism industry. The need to improve the system of vocational education in the tourism industry is caused by the social demand, which is changing under the influence of globalisation processes in Ukraine and in the world. Now a separate approach in professional pedagogy has been determined, which is pedagogy of tourism. Theoretical principles of tourism pedagogy were discussed in the works of Ukrainian researchers Sakun (2004); Fedorchenko et al. (2004), and others. According to L. Sakun, pedagogy as a science is constantly evolving and changing, which leads to the emergence of new fields such as pedagogy of the tourist personality, pedagogy of culture, pedagogy of tourist communication, pedagogy of tourism and pedagogy of international tourism, pedagogy of tourism history, pedagogy of social tourism, pedagogy of tourism activity (Belhassen \& Caton, 2011; Fullagar \& Wilson, 2012). The scholar defines the pedagogy of tourism as a relatively new approach in pedagogy, which subject matter is the process of development the personality of a highly qualified specialist in the tourism industry. Representatives of this section of pedagogy consider the pedagogy of tourism as a masterful education of a new type of a specialist in tourism, which can withstand significant competition in the labour market at the present stage of human development (Fedorchenko et al., 2004).

M. Skrypnyk clarifies the concept of pedagogy of tourism as a science by giving it a broader meaning, namely: the study of the processes of education, training and personal development in the context of humanitarian and social functions of tourism (Minguez et al., 2021; Rouzrokh et al., 2017). According to the scholar, the subject matter of tourism pedagogy is "a special form of public consciousness of a person's education (components of which are education and training) during one's stay for health, cognitive or business purposes in another place and education of tourism professionals" (Sakun, 2004). In addition, V. Fedorchenko, who believes that: "taking into account the features of tourism, it is possible to give a specific definition of pedagogy as a science of education and upbringing through tourism and to develop tourism. Indeed, in relation to the tourist's personality, pedagogy is focused on the educational impact, and in relation to the tourism specialist - on education". Thus, the subject matter of the research in tourism pedagogy is education as a function of transferring accumulated values to tourists such as knowledge, life experience. Another subject matter of the study is the pedagogical system of tourism education as a means of transforming a new generation of professional knowledge, competences, and skills in tourism activities (Fedorchenko, 2002). After analysing opinions of Ukrainian scholars, it could be concluded that the priority of tourism pedagogy as a science is to reveal the patterns in the field of education through tourism, tourism education and training, as well as the management of educational systems. Thus, according to V. Fedorchenko, pedagogy of tourism can be defined as the science of education and development of personality by means of tourism in the process of travelling. At the same time, pedagogy of tourism as a science that provides professional training in the field of tourism and tourism industry, in particular. Despite the 
valuable results in the scholar's studies, the problem of effective training of future tourism specialists as a specialist able to conduct intercultural communication at a high professional level to meet the growing needs of consumers in the industry remains relevant (Cetinavci, 2012; Spencer-Rodgers \& McGovern, 2002).

\section{Materials and Methods}

Excursion method is the basis of the tour and is a compilation of methods and techniques for communicating knowledge. The basis of these methods is clarity; obligatory combination of two elements is show and story; optimal interaction of three components is the guide, sightseeing objects and tourists; movement of tourists (motor skills) through a certain route to study objects in their natural location. The complex nature of the excursion method is revealed due to the means of communication of knowledge by the guide and the reception of this knowledge by tourists. Among the teaching methods borrowed by tourist guides from pedagogy, there are verbal, visual and practical methods. In their storytelling, guides use verbal methods, oral presentation of information, conversation, explanations, retelling the plot of a particular literary source, and explanatory reading. A large part of the presentation uses visual methods such as demonstration of the studied objects in nature or in images; practical methods, which imply tourists' independent work on mastering the information, review of objects, etc. The perception of the excursion material is based on a combination of three types of mental processes: cognitive (feeling, thinking, imagination), emotional (experience), volitional (efforts to maintain attention, activation of memory).

Excursion method uses a variety of means to enhance the perception of the material, while taking into account the achievements of methods of psychology. Various forms of storytelling play an important role here. One of them is a problematic presentation of the material. The guide asks a question that needs to be solved and involves participants in finding the necessary answer. Another method is to transition from monologue to dialogue in the story. In excursion practice, analogy method is widely used since it involves the activation of various associations of tourists. Using the inductive method, the guide summarises individual facts and draws conclusions based on the presented material, moving from specific aspects to general concept, from individual facts to general conclusions. Using the deductive method, one develops the idea from general concept to specific aspects and proves the thesis presented at the beginning by using arguments. Inductive and deductive methods of cognition have the same significance for the methodology as analysis and synthesis. However, there is a significant difference in their application. If induction and deduction are used in the storytelling, analysis and synthesis are used in the part of the tour, which is tentatively called "the show". The essence of the excursion analysis involves a detailed study of the object by imaginary dividing it into parts with the emphasis on their features, which is aimed at developing the concept of the environment. Among the types of excursion analysis there are:

- Art criticism, which is used as a method of displaying works of art and architecture. It allows revealing the idea of the work, explaining the means 
and methods of creating an artistic image. Methods of art analysis depend on the type of art.

- Historical analysis enables an in-depth evaluation of information in terms of the most prominent features of a particular era, revealing the connection of the tour object with historical events.

- Natural science analysis reveals the most significant properties of objects during natural excursions.

- Production and economic analysis are the development of the essence of process technology and the economic basis for the certain types of human activities.

When interacting with the audience, the guide uses methods of pedagogical influence, which are based on didactic principles (scientific, ideological, connection with real life, accessibility, system, responsiveness and persuasiveness). They define the content, organisation and methods of educating tourists during the excursion, regardless of them being children or adults. Therefore, the excursion method is the basis of the tour and is a compilation of the ways for the guide to share the knowledge and tourists' reception of this knowledge.

\section{Results and Discussion}

Dictionaries and guidebooks on modern tourism record the meaning of basic concepts used at various levels in this field such as "tourism", "international tourism", "diplomacy" and "people's diplomacy". "People's diplomacy" means the exchange of delegations from non-governmental institutions, public organisations and associations, which represent the public interest within intercultural communication but from an informal standpoint (Arasaratnam \& Doerfel, 2005; Martin, 2015). Since the development of mutually beneficial cooperation between different social groups establishes multifaceted democratic connections with the outside world, the task of public diplomacy is to protect them (Edelheim, 2020). The importance of tourism as a factor of "people's diplomacy" is especially relevant considering the tragic events that have taken place in recent decades and continue to take place in various countries around the world, including Ukraine. However, at any level of international relations development, participants in these processes must be prepared for productive intercultural interaction. A wide range of specialisations of tourism professionals is required due to the need to meet the variety of needs of the tourism market consumers (Lee \& Moon, 2020). Tourist establishments should employ highly qualified specialists who speak basic foreign languages. Evidently, managers' communication without mediation interpreters with both guides and tourists contributes to the good working rhythm, quick solutions of problems, enhancement of trust and better attitude of foreigners to the officials of tourist organisations (Berezovska \& Rusyn, 2019).

Notably, in this context, increasing the level of professional training of tourism workers to communicate with representatives of different societies depends on the quality of their preparation for intercultural communication, as well as the level of foreign language proficiency and knowledge of various needs of different categories of tourists. When shaping the experience of productive tolerant intercultural communicative interaction of future specialists N. Yaksa refers to its 
components, which are socio-cultural environment, upbringing and practice, which are performed through education; being familiar with global culture and universal values and standards of living at the same time; development of spiritual potential and new ways of thinking within the framework of civil human rights; perception of the history of one's nation through the historical past of one's country and humanity in general, and oneself who cares national values and responsibility for the future of humanity; development of understanding of the integrity of the modern world, interdependence of all events and processes, the need to unite the efforts of representatives of different cultures to solve global problems; recognition of equality and dignity of all cultures and the right of representatives of other cultures to preserve their cultural identity, etc. (Yaksa, 2006). The intercultural component of professional communication helps the student to form a holistic view of education, designed on the basis of dialogue of cultures, which allows involving the future professionals in the cultural heritage of the world.

In terms of designing intercultural interactive exchange, professional training of a guide involves taking into account the aspect of intercultural dialogue. L. Yevdokimova-Lysohor interprets intercultural dialogue of a tourism specialist as "professional and business interaction with representatives of different cultures and languages, acquisition of creative skills of dialogic interaction in professional activity" (Dashevska \& Tomkovich, 2018; Yevdokimova-Lysohor, 2018). Hence, intercultural communication can be seen as a purposeful connection between different cultures, where an exchange of information, cultural and spiritual values occur, while taking into account the uniqueness of every culture in professional activities to meet the needs of tourists and intercultural dialogue. To avoid communicative contradictions, it is necessary to understand the contexts that occur, which are the context of the real situation and the contexts of individual participants of communication. Understanding contexts is a method for comprehending the cultural dialogue, which can be seen as a means of communicative interaction between individuals or groups of people who belong to different cultures. Tourism services employers and consumers' modern requirements for tourism professionals derive from competition in the labour market. Thus, the professional training of a specialist in this field should focus on ensuring a high level of their theoretical and practical training, readiness for professional, as well as communicative interaction with consumers of tourist services.

Nowadays, advanced training is also an important and necessary condition for the guides' practice. Improving the professional skills of guides is contributed by training tours (without the participation of a group led by an experienced teacher and curriculum developer), educational and demonstration tours (conducted by experienced teachers and curriculum developers), field trips, special exercises for memorising, observation. As a rule, advanced training at any organisations or training centres, which is certified by the relevant documents (license, certificate), is proposed for self-paid students. There are various forms of professional development of guides. First of all, these are seminars that can be organised by employment centres, tourism committees, faculties of advanced training in higher education establishments, individual entities of the tourism industry. The topics of these seminars relate to the issues of excursion activities such as ethics of 
communication with tourists, safety during excursions and issues of accident insurance, problems of formation of the contracts for excursion services, liability of the parties for breaching the contract. As a rule, these seminars involve guides with working experience. The duration of the seminars is 1-2 days. The second form is advanced training courses for guides (50-70 academic hours for 3-4 months). The training programme usually includes the study of new excursion routes, new topics, programmes for individual tours. Third form is training courses for novice guides. The duration of courses is not less than 100 academic hours. Upon completion, documents such as a certificate and a license are issued. An approximate plan for training and retraining courses for guides and guides-interpreters is designed for 100-150 academic hours. As a result, students master the following skills and gain experience in: methods of preparation and conduct of sightseeing tours; methods of developing original excursions; methods of historical interpretation; cultural and natural heritage; methods of development and testing of tourist routes; use of information resources during the compilation of control texts for excursions. As a rule, the programme of such courses includes studying features of geological, geographical, historical and ethnographic development of the region; educational and methodical excursions and study of the objects of the exhibition; practice of giving the excursions. The training consists of three logically connected blocks:

- Educational and methodical preparation of students for the test;

- Methods of conducting a sightseeing tour;

- Educational and methodical preparation of students for the exam.

Travel agencies, excursion bureaus, training centres, employment centres, secondary and higher vocational schools, tourism committees in cooperation with educational institutions can provide training and advanced training services. Training and retraining courses for guides exist at many governmental and nongovernmental organisations in Ukraine. Kyiv Institute of Industrial Training constantly conducts courses within the programme "Guide". The courses last 2.5 months. After these courses, students receive official permission to conduct tours in Kyiv and receive standard documents. Since 1986, the State Enterprise "Training and Consulting Centre for Tourism" existed in Ukraine as a branch of the All-Union Institute for Advanced Training of Managers and Specialists of the State Committee for Tourism. Nowadays it is a state educational institution, which is included in the State Register of Postgraduate Education Institutions and provides courses in many fields on a level of higher education. This centre provides distance and field training of guides and guides-interpreters in Lviv, Kharkiv, Zhytomyr, Ivano-Frankivsk, Sumy and other Ukrainian cities. In Lviv, several institutions also train guides. Limited Liability Company Mandry Plus Centre is engaged in training and retraining for the tourism industry in fields that are not included in the programmes of educational institutions engaged in general training of specialists in tourism (Kovalenko, 2019).

The Lviv Association for Tourism Development is also recruiting for a licensed Course for Guides and Translators. Course duration is 3 months. Upon completing courses, state documents are issued. Despite the fact that tourism education in Ukraine trains specialists at a high level, there is a problem of providing the industry with potential staff due to the relatively low level of 
cooperation between tourism schools and tourism enterprises. Therefore, fields of joint activity such as the integration of the work of tourism professionals and educational institutions through consultations, practical tasks, participation in training, etc. are also important. The participation of teaching staff in the professional activities of the tourism field (working in companies as guides, tour operators, etc.) is required. The qualitative result of this cooperation is the integration of preparedness and ability of graduates to perform professional activities. For analysis purposes, the training programmes of other countries were divided into three categories to present an objective picture of the opportunities for training, retraining and certification of guides, interpreters and instructors in Europe and the United States, Asia, Africa, and Australia.

The analysis of the programmes in the category "European countries and the USA" showed that there are many schools and institutes for advanced training and retraining. However, a permission for work can only be obtained if it is certified by an officially recognised organisation (for example, in Spain it is the Asociaciones Profesionales de Guias de Turismo; in the USA it is a regional organisation such as the Chicago Professional Association of Guides, in the UK it is the Association of Professional Tourist Guide and Institute of Tourist Guiding). In addition, in the countries of this category there are many types of guides (guides-interpreters, guides-drivers, speleo-guides, eco-guides, guides for services in the sacred places, guides who work on the same route, art guides and etc.) and a clear restriction by the territory, i.e., the documents of the guide define in which region one has the right to work (for example, in Spain, if the guide was certified and licensed to work in Barcelona, then to work in another region one needs to be re-certified in this region). This is a very rational approach, which gives additional confidence to tourists that their guide has a deep knowledge of the region, its historical and cultural features, etc.

In Asia and Africa, supplementary education in tourism is provided mostly by the short-term and summer courses, and vocational educational programs (Skobkin et al., 2020). But there are also programmes that last up to a year and focus on improving the skills of specialists in these fields. Most educational institutions in the Asian and African regions are members of National Tourism Associations/ Organisations, which, in their turn, are members of the World Tourism Organisation (European Federation of Tourist Guide Associations, 2021). In Australia, as evidenced by numerous universities and schools the development of tourism and education in general are carefully considered. Universities and colleges hold year-round courses in various programmes in the field of tourism. Assessment of the level of training and preparedness for work is done by Guiding Organisations Australia (GOA), which has been recognised by the country's leadership and representatives of the tourism industry (Table 1).

Table 1

Analysis of foreign experience in organising supplementary education in the field of tourism

\begin{tabular}{llll}
\hline & $\begin{array}{l}\text { Europe and the } \\
\text { USA }\end{array}$ & $\begin{array}{l}\text { Asian and African } \\
\text { Countries }\end{array}$ & Australia \\
\hline Subjects of & University (Great & University of Hawai i; & William Angliss \\
\hline
\end{tabular}




\begin{tabular}{|c|c|c|c|}
\hline $\begin{array}{l}\text { SPE } \\
\text { (supplementary } \\
\text { professional } \\
\text { education) }\end{array}$ & $\begin{array}{l}\text { Britain), Jaume I } \\
\text { University } \\
\text { (Spain), } \\
\text { International } \\
\text { school of tourism } \\
\text { sciences (Italy), } \\
\text { School of Tourist } \\
\text { Guides in Greece } \\
\text { (Greece), Iceland } \\
\text { Tourist Guide } \\
\text { School (Iceland) }\end{array}$ & $\begin{array}{l}\text { Hawai'i International } \\
\text { Hotel Institute; The } \\
\text { Singapore Hotel and } \\
\text { Tourism Education } \\
\text { Centre (SHATEC); Haikou } \\
\text { Vocational Tourism } \\
\text { School; Korea Tourism } \\
\text { Organisation; Indian } \\
\text { Institute of Tourism and } \\
\text { Travel Management } \\
\text { (IITTM); East Asia } \\
\text { Institute of Management } \\
\text { (EASB). }\end{array}$ & $\begin{array}{l}\text { Institute, } \\
\text { International } \\
\text { College of } \\
\text { Management, } \\
\text { Sydney, } \\
\text { University of } \\
\text { Ballarat, } \\
\text { Flinders } \\
\text { University. }\end{array}$ \\
\hline $\begin{array}{l}\text { The presence } \\
\text { of a } \\
\text { coordinating } \\
\text { SPE structure }\end{array}$ & $\begin{array}{l}\text { Most training } \\
\text { entities are } \\
\text { members of } \\
\text { associations and } \\
\text { unions } \\
\text { (institutes). In the } \\
\text { countries of the } \\
\text { European Union } \\
\text { and in the USA, } \\
\text { there are } \\
\text { organisations } \\
\text { that control the } \\
\text { issuance of rights } \\
\text { and certificates } \\
\text { for the right to } \\
\text { engage in tourism } \\
\text { activities in a } \\
\text { centralised way. }\end{array}$ & $\begin{array}{l}\text { Field Guide Association of } \\
\text { South Africa, Government } \\
\text { of Fr. Hainan (China), } \\
\text { Appraisal Centre and } \\
\text { Training Centre of } \\
\text { Professional Skills, local } \\
\text { education departments. }\end{array}$ & $\begin{array}{l}\text { Government } \\
\text { agencies, } \\
\text { including the } \\
\text { Department of } \\
\text { Hospitality and } \\
\text { Tourism. }\end{array}$ \\
\hline $\begin{array}{l}\text { General } \\
\text { concept and } \\
\text { methodology of } \\
\text { SPE } \\
\text { programmes }\end{array}$ & $\begin{array}{l}\text { There are courses } \\
\text { for training } \\
\text { specialists in } \\
\text { specific fields } \\
\text { such as art guide, } \\
\text { guide to } \\
\text { meetings, guide } \\
\text { to sightseeing } \\
\text { tours, etc. The } \\
\text { training } \\
\text { programme } \\
\text { includes studying } \\
\text { the history of the } \\
\text { region where the } \\
\text { activity will be } \\
\text { carried out; } \\
\text { compulsory } \\
\text { second/additional } \\
\text { language study; }\end{array}$ & $\begin{array}{l}\text { Promoting the training of } \\
\text { guides through education } \\
\text { that meets FGASA and } \\
\text { National Training } \\
\text { standards; improving } \\
\text { management skills, } \\
\text { exchange of professional } \\
\text { experience. }\end{array}$ & $\begin{array}{l}\text { The } \\
\text { programmes } \\
\text { are targeted } \\
\text { and designed } \\
\text { for those who } \\
\text { are already } \\
\text { working in the } \\
\text { field of } \\
\text { tourism, } \\
\text { hospitality and } \\
\text { event tourism, } \\
\text { especially at } \\
\text { the operational } \\
\text { level, as well as } \\
\text { for those who } \\
\text { are interested } \\
\text { in developing } \\
\text { knowledge and } \\
\text { skills in this }\end{array}$ \\
\hline
\end{tabular}




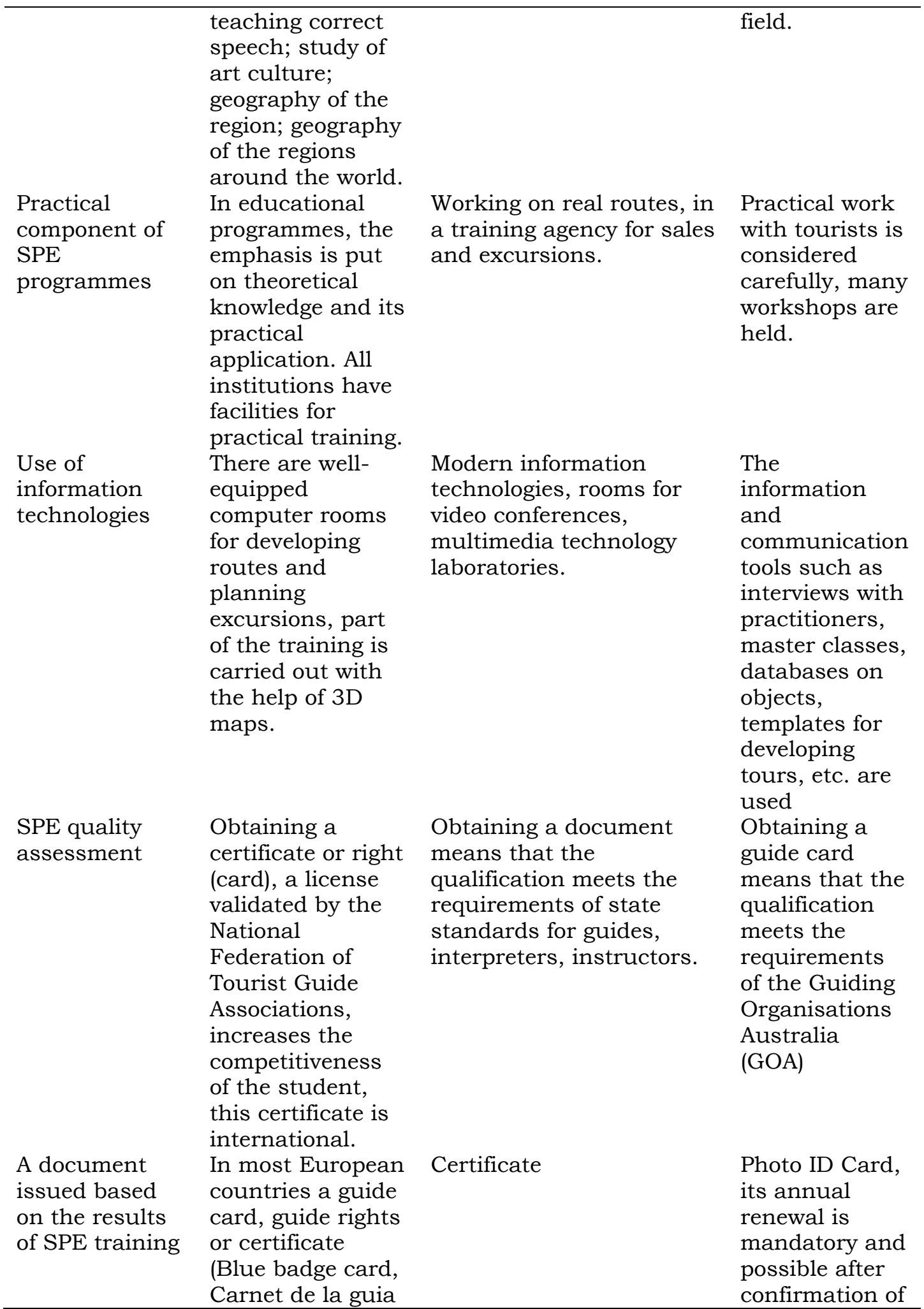




\begin{tabular}{|c|c|c|c|}
\hline \multirow{20}{*}{$\begin{array}{l}\text { Control in the } \\
\text { system }\end{array}$} & turistica) is & \multirow{20}{*}{$\begin{array}{l}\text { Field Guide Association of } \\
\text { South Africa, Government } \\
\text { of Fr. Hainan (China) }\end{array}$} & \multirow[t]{7}{*}{ qualification. } \\
\hline & issued, in the & & \\
\hline & USA a certificate & & \\
\hline & (Tour guide & & \\
\hline & certificate) is & & \\
\hline & issued for & & \\
\hline & confirmation. & & \\
\hline & The issuance & & The document \\
\hline & $\begin{array}{l}\text { system in Europe } \\
\text { and the United }\end{array}$ & & is overseen by \\
\hline & States is & & Organisations \\
\hline & controlled by the & & Australia \\
\hline & country's & & (GOA) and the \\
\hline & professional & & Department of \\
\hline & associations, & & Hospitality and \\
\hline & government & & Tourism. \\
\hline & agencies and/or & & \\
\hline & the NFTGA & & \\
\hline & (National & & \\
\hline & Federation of & & \\
\hline & associations). & & \\
\hline
\end{tabular}

In April 2016, parliamentary hearings on tourism in Ukraine regarding standardisation and professional development of tour guides were held, where it was proposed to adopt a European standard for training guides along with a dozen other European standards. This standard regulates the training, retraining and performance standards for tour guides. The training of guides should be based on the requirements of the European standard EN 15565: 2008. This year, the European Union has revised many of its standards and prolonged the operation of this standard for another ten years. The purpose of standardisation is the mutual recognition of the qualification of a tourism guide in the countries of the European Union, as well as ensuring the compatibility of the quality of the guide's activities within the international context. European standard EN 15565: 2008 sets minimum requirements for the training of tour guides and training programmes. However, the requirements for training programmes defined in the standard are minimal and do not hinder supplementary training or additional methods of assessment of competence (DSTU EN 15565: 2016 (EN 15565: 2008, IDT), 2016).

The standard determines that the guide training program should be designed so that future tour guides can: 1) represent the region (place, city, region and/or country); 2) lead groups or individual visitors (visitors with special needs in particular) to natural and artificial attractions; 3) study the information to give accurate and relevant comments; 4) interpret the cultural and natural heritage and the environment for the visitors; 5) help visitors understand what they are seeing and/or visiting; 6) inform visitors about all relevant aspects of life in the region; 7) create and/or develop excursions in one's region; 8) submit the material properly. The training program should be designed so that tour guides also have the opportunity to assess their audience, adapt to the interests and needs of 
visitors by selecting relevant information, present the information to the fullest and in an appropriate manner. The training programme should be designed so that tour guides gain knowledge of the tourism industry and visitor profiles in their area; relevant rules and regulations, including health and safety; tax insurance claims; marketing and features of tourism business (European Standard 15565: 2008: Tourism services..., 2008).

This standard also defines the requirements for regionally specific subjects. A guide training program should be designed to teach how to interpret the region's cultural heritage. It should include such recommended subjects as history (political, social and economic), archaeology, art history, architecture, geography and geology, natural heritage, ecology, flora and fauna, weather and climate, art, literature and linguistics, customs (folklore, traditions and mythology), economics, agriculture, industry, services, modern life (legal and political system; education system; social assistance and health care systems; science; intercultural issues; recreation, leisure, entertainment and sports food and beverages, celebrities). The training programme for future tour guides should include some specific subjects, such as the basics of working conditions related to the profession of tour guide; public, trade, labour and tax legislation and social security; the concept of public and private professional organisations related to the profession of tour guide; legislation in the field of tourism and cultural heritage (Kovalenko, 2019; Yepyk \& Kovalenko, 2020).

The standard emphasises the practical training of future guides. It is stated that the programme of practical training should include demonstration tours and excursions to places, monuments, and all major heritage sites of the region. $\mathrm{N}$. Nychkalo, when analysing theoretical materials on pedagogy, psychology and tourism as a component of the theory and methodology of vocational education, noted that one of the most important aspects of Ukrainian vocational tourism education is the justification and study of cultural principles of vocational education (Nychkalo, 2000). The network of tourist communication allows for a global synergy of cultures, when they develop and improve while unconditionally preserving their identity (Ushakov et al., 2021). Tourists and locals are seen as bearers of humanitarian values, which they exchange during their communication. As a result, there is an intensification and deepening of interaction, mutual influence, interflow and enrichment of cultures. Therefore, tourism through a system of different social institutions can cause "direct (through direct contact of their representatives) humane communication of societies, and their interaction on the basis of human-cantered parameters of order (including social). It focuses on humanitarian values, social programmes, projects, goals, ideals and promotes self-organisation of a humane global society" (Hwang \& Lee, 2019).

Therefore, it should be noted that mutual understanding is the result of a properly organised dialogue between representatives of different cultures. "Dialogue, which contains all the accumulated communicative potential of humanity (conversation and debate, competition and cooperation, tirade and opposition) develops both individual's self-esteem and respect for others." As a rule, a tourist is a person of "dialogic style" (Maddamsetti, 2020), who possesses cultural qualities inherent for one's society. Along with the progress in the 
informatisation of society, there are such negative phenomena as lack of contacts and communication between people, communicative limitations, loneliness. It is necessary to intensify dialogic ties as the basis of modern communicative culture for intercultural dialogue to reduce the negative consequences of informatisation of society. Here, the cultural function of tourism plays an important role, which, according to O. Holovashenko, is developed by using the model of interaction of four cultures, which are the culture of the region where tourists come to; leisure culture; original culture of locals; service culture. For effective communication, communicative culture must correspond to the current level of development of civilisation (Holovashenko, 2002).

Intercultural communication occurs between representatives of different cultures, during which communicators show their experience, knowledge and values, revealing the essence of culture. Therefore, most foreign scholars see it as an interaction between different cultures, which has a dual nature, it is a special branch of human relations that combines communication and culture. Based on the conceptual theses of psychologists, the intercultural communication could be defined as the interaction of cultures, which takes place in a certain space and time; cultural contacts, which take different forms, are expressed through rapprochement, synthesis, additional information, dialogue, language; in this type of communication, they interact (occur) through language, culture and personality (Telychko \& Zavydovska, 2020). When analysing studies in the field of intercultural communication, the authors conclude that the attention of scholars was mainly focused on the causes of barriers and misunderstandings in intercultural communication and possible ways to overcome them, the study of behaviour in an intercultural environment, especially, for successful management professional activity, personnel management or establishing business relations between communicators. There should be paid more attention to the personal development of the future specialist for effective intercultural communication, the development of one's cultural beliefs and values, as well as one's development as a professional to meet the described needs.

\section{Conclusions}

Thus, the important aspects of professional training of the future guide for the implementation of intercultural communicative interaction in professional activities include awareness of the cultural function of tourism; the need for basic psychological knowledge about the problems of intercultural communicative interaction for the development of values in the world (mutual respect for each other, tolerance, knowledge of individual features, the adequacy of emotions, ways and means of communicative actions and behaviour of communication partner); the intercultural component of professional training is considered as a tactic, which helps the future specialist to see the common and special features in different cultures that unite and divide them, to learn to communicate from the standpoint of intercultural dialogue; understanding of intercultural communicative interaction as a purposeful connection between representatives of different cultures, where an exchange of information, cultural and spiritual values occurs, while taking into account the uniqueness of every culture in professional activities to meet the needs of tourists; preparedness to eliminate the contradictions of communication (the constructive nature of communication, 
which deepen, improve and develop the relationship, and the destructive nature of communication, which destroys the relationship).

Hence, the application of a cultural studies approach to the training of a tourism specialist is important. This, in its turn, necessitates the filling of training programs for tourism professionals (guides) with cultural meaning and emphasises the need to create appropriate educational and methodological support for this process for future professionals to obtain professionally important qualities necessary for successful career and relevant skills for highquality communicative interaction with representatives of other cultures. In addition, the problems of training of guides require the modern system of vocational education to develop basic competencies, as well as to determine the content and methods of training specialists in this field. Nowadays, it is necessary to define and approve at the legislative level of the standard of training guides in accordance with European requirements. The European standard EN 15565: 2008 "Requirements for professional training of tourist guides and qualification training programs" mentioned in this study can become a base for training guides in Ukraine, but it needs additions with consideration of regional and sociocultural components.

\section{References}

Absatova, M., Aituarova, A., Ospanbekova, M., Azhgaliyev, M., Uanbayev, E., \& Doshybekov, A. (2021). Experimental research of motivational and reflexive components of students' reading culture. Linguistics and Culture Review, 5(S1), 670-683. https://doi.org/10.21744/lingcure.v5nS1.1451

Amandykova, S. K., Syrlybayev, M. K., Saimova, S. A., Altynbassov, B. O., Suleimenova, S. Z., Berdiyarova, Z. S., ... \& Askarova, A. O. (2016). The role of science and education in the formation of national human capital: Kazakhstani experience.

Ang, B. W. (2005). The LMDI approach to decomposition analysis: a practical guide. Energy policy, 33(7), 867-871. https://doi.org/10.1016/j.enpol.2003.10.010

Arasaratnam, L. A., \& Doerfel, M. L. (2005). Intercultural communication competence: Identifying key components from multicultural perspectives. International journal of intercultural relations, 29(2), 137-163. https:/ / doi.org/10.1016/j.ijintrel.2004.04.001

Báez, A. B., Dominguez, D. C., \& Terceño, J. R. (2020). Integración de la Educación Emocional como Nuevo eje Conformador en el Grado Universitario de Turismo.

Belhassen, Y., \& Caton, K. (2011). On the need for critical pedagogy in tourism education. Tourism Management, 32(6), https://doi.org/10.1016/j.tourman.2011.01.014

Berezovska, L. I., \& Rusyn, Ye. V. (2019). Psychological aspects of the competitiveness of future specialists in the tourism industry. Bulletin of Mukachevo State University. Series "Pedagogy and Psychology", 1(9), 252-255.

Bretsko, I. I., \& Morgun, I. V. (2019). The impact of non-verbal communication means in the process of intercultural communication. Bulletin of Mukachevo State University. Series “Pedagogy and Psychology”, 2(10), 194-197. 
Caber, M., Ünal, C., Cengizci, A. D., \& Güven, A. (2019). Conflict management styles of professional tour guides: A cluster analysis. Tourism Management Perspectives, 30, 89-97.

Cetinavci, U. R. (2012). Intercultural communicative competence in ELT. Procedia-Social and Behavioral Sciences, 46, 3445-3449. https://doi.org/10.1016/j.sbspro.2012.06.082

Dashevska, I. M., \& Tomkovich, O. I. (2018). Interactive teaching methods and their application in excursion activities. Bulletin of Taras Shevchenko Luhansk National University, 4(239), 129-134.

Di Nezza, E., Palatucci, G., \& Valdinoci, E. (2012). Hitchhiker's guide to the fractional Sobolev spaces. Bulletin des sciences mathématiques, 136(5), 521573. https://doi.org/10.1016/j.bulsci.2011.12.004

Edelheim, J. (2020). How should tourism education values be transformed after 2020?. Tourism Geographies, 22(3), 547-554.

Fatmawati, E. (2021). Strategies to grow a proud attitude towards Indonesian cultural diversity. Linguistics and Culture Review, 5(S1), 810-820. https://doi.org/10.21744/lingcure.v5nS1.1465

Fedorchenko, V. K. (2002). Training for tourism: Theoretical and methodological aspects. Kyiv: Vyshcha Shkola.

Fedorchenko, V. K., Fomenko, N. A., Skrypnyk, M. I., \& Tsekhmistrova, G. S. (2004). Pedagogy of tourism. Kyiv: Slovo Publishing House.

Fullagar, S., \& Wilson, E. (2012). Critical pedagogies: A reflexive approach to knowledge creation in tourism and hospitality studies. Journal of Hospitality and Tourism Management, 19(1), 1-6. https://doi.org/10.1017/jht.2012.3

Ghahramani, L., Khalilzadeh, J., \& Birendra, K. C. (2018). Tour guides' communication ecosystems: an inferential social network analysis approach. Information Technology \& Tourism, 20(1), 103-130.

Gültekin, S., \& Icigen, E. (2019). A research on professional tour guides emotional intelligence and problem-solving skills. Journal of Quality Assurance in Hospitality \& Tourism, 20(2), 230-258.

Holovashenko, O. V. (2002). Tourism as a form of human social activity: A sociophilosophical analysis: thesis of candidate of philosophical sciences. Zaporizhzhia: Zaporizhzhia National University.

Hwang, J., \& Lee, J. (2019). Relationships among senior tourists' perceptions of tour guides' professional competencies, rapport, satisfaction with the guide service, tour satisfaction, and word of mouth. Journal of Travel Research, 58(8), 1331-1346.

Kovalenko, O. V. (2019). Basic principles of forming the content of professional training of tourist support specialists (guides) in Belarus and Ukraine. Bulletin of Luhansk National University. Pedagogical Sciences, 6(329), 46-53.

Lee, W. S., \& Moon, J. (2020). Development of a Personal Values Scale For Tourism Using a Mixed Method. Tourism Culture \& Communication, 20(4), 207218.

Litovka-Demenina, S. (2019). Marketing culture of future specialists in the sphere of tourism. Bulletin of Mukachevo State University. Series "Pedagogy and Psychology", 1(9), 81-83.

Liu, X. (2018). International Publicity Translation of Tourism Culture in Central China from the Perspective of Skopos Theory. International Journal of Linguistics, Literature and Culture, 4(2), 1-8. Retrieved from https://sloap.org/journals/index.php/ijllc/article/view/38 
Maddamsetti, J. (2020). Cultivating culturally relevant and sustaining pedagogy through field experiences: discourses of elementary preservice teachers of colour. New Educator, 16(4), 352-375.

Martin, J. N. (2015). Revisiting intercultural communication competence: Where to go from here. International Journal of Intercultural Relations, 48, 6-8. https:/ / doi.org/10.1016/j.ijintrel.2015.03.008

Miloradov, K. A., Romanishina, T. S., Kovalenko, A. A., Bondarenko, N. G., \& Andrianova, J. V. (2018). An efficient strategy for the development of tourism at regional level.

Minguez, C., Martínez-Hernández, C., \& Yubero, C. (2021). Higher education and the sustainable tourism pedagogy: Are tourism students ready to lead change in the post pandemic era?. Journal of Hospitality, Leisure, Sport \& Tourism Education, 29, 100329. https://doi.org/10.1016/j.jhlste.2021.100329

Nychkalo, N. H. (2000). Research of problems of pedagogy and psychology and tourism as a component of the theory and methods of vocational education. In: Tourism on the Threshold of the 21st Century: Education, Culture, Ecology: Conference Proceeding 18-20 October 1999 (pp. 257-261). Kyiv: KITEP.

Rouzrokh, M., Muldoon, M., Torabian, P., \& Mair, H. (2017). The memory-work sessions: Exploring critical pedagogy in tourism. Journal of Hospitality, Leisure, Sport \& Tourism Education, 21, 163-173. https://doi.org/10.1016/j.jhlste.2017.08.006

Sakun, L. W. (2004). Theory and practice of training specialists in the field of tourism in developed countries. Kyiv: Interregional Academy of Personnel Management.

Shmeleva, N. V., \& Spasskii, A. N. (2018). Features of culturology as an academic discipline: goals, objectives. Perspektivy Nauki i Obrazovania, 33(3), 179-183.

Skobkin, S. S., Miloradov, K. A., \& Kovaltchuk, A. P. (2020). The Development of Hospitality and Tourism Industry in Africa. Journal of Environmental Management \& Tourism, 11(2 (42)), 263-270.

Spencer-Rodgers, J., \& McGovern, T. (2002). Attitudes toward the culturally different: The role of intercultural communication barriers, affective responses, consensual stereotypes, and perceived threat. International journal of intercultural relations, 26(6), 609-631. https://doi.org/10.1016/S01471767(02)00038-X

Suwija, N., Suarta, M., Suparsa, N., Alit Geria, A.A.G., Suryasa, W. (2019). Balinese speech system towards speaker social behavior. Humanities \& $\begin{array}{llll}\text { Social Sciences } & \text { Reviews, } & \text { 3(5), } & \end{array}$ https://doi.org/10.18510/hssr.2019.754

Suyasa, I. M., Kusuma, I. N. W., \& Suarka, I. N. (2016). Revealing the religious meaning of bakayat sasak oral-text. International Journal of Linguistics, Literature and Culture, 2(4), 122-128.

Telychko, N. V., \& Zavydovska, D. (2020). Foreign language training for professional intercultural communication as one of the components of modern legal education. Scientific Bulletin of Mukachevo State University. Series "Pedagogy and Psychology", 1(11), 186-188.

Ushakov, D. S., Kiselev, D. N., Zezyulko, A. V., Imangulova, T. V., Kulakhmetova, G. A., \& Kulakhmetova, R. A. (2021). Organization of network basis for transnational tourism activity. Geojournal of Tourism and Geosites, 34(1), 7787. 
Yaksa, N. W. (2006). Theoretical bases of professional and pedagogical preparation of future teachers for interaction of subjects of educational process in the conditions of multiculturalism of the Crimean region. Zhytomyr: Publishing of Zhytomyr Ivan Franko State University.

Yepyk, L., \& Kovalenko, O. (2020). Innovative technologies in modern cultural education. European vector of modern cultural studies and art criticism: the experience of Ukraine and the Republic of Poland. Riga: Izdevnieciba "Baltija Publishing".

Yevdokimova-Lysohor, L. A. (2018). Preparation of future specialists in the field of tourism for intercultural dialogue in the process of studying socio-humanitarian disciplines: thesis of candidate of pedagogic sciences. Kropyvnytskyi: Volodymyr Vynnychenko Central Ukrainian State Pedagogical University. 